\title{
The U.S. Food and Drug Administration Should Solidify the Legal Basis for Its Authority over Reproductive Cloning
}

\author{
Bernard Siegel ${ }^{1, *}$ and Arnold I. Friede ${ }^{2}$
}

\section{ABSTRACT}

The promise and potential of stem cell research is apparent. However, ethical questions still linger. There is as yet no consensus in the U.S. Congress on how to address the issue of reproductive cloning and media confusion of this and the quite separate issue of therapeutic cloning inhibits therapeutic advance. This paper outlines the need for the FDA to undertake a deliberate process, with input from all stakeholders, to authoritatively establish its jurisdiction over human reproductive cloning so as to foster the life-saving potential of therapeutic cloning.

Everywhere you turn today the promise and potential of stem cell research is apparent. Recently, for example, researchers at the Oregon Health \& Science University reported that they had successfully derived six pluripotent, embryonic stem cell lines created by somatic cell nuclear transfer (SCNT) [1]. Although questions have been raised about errors in the report over duplication of figures, the experiment has, nevertheless, been acclaimed as a historic achievement with important clinical implications (see, e.g., [101]). Indeed, the genetic identity of these stem

\footnotetext{
${ }^{1}$ Genetics Policy Institute, Palm Beach, Florida.

2 Arnold I. Friede \& Associates, Boca Raton, Florida.

*(Correspondence: bernard@genpol.org)
}

cells to the patient's own cells dramatically reduces the risk of rejection should they be used in actual therapy [102]. At the same time, nagging ethical questions, such as the creation of a cloned human embryo and its possible use in reproductive human cloning, still linger [102].

It is true, of course, that all responsible organizations in the field oppose human reproductive cloning, and that a few states have enacted legislative and even constitutional prohibitions on the practice [102]. However, there is no consensus in the U.S. Congress on how to address the issue. There, the question of reproductive cloning remains stuck in the ongoing political debate over human embryonic stem cell research for use in SCNT (or, as it is more commonly referred to in the media, therapeutic cloning) - and vice versa. However, the commingling of reproductive cloning with therapeutic cloning raises the distinct possibility that the ethical concerns about the former will spill over to the latter and result in a broad prohibition of SCNT. This would have profoundly negative consequences for the discovery of important new treatment modalities that are on the horizon. Thus, it is necessary to put the question of reproductive cloning behind us once and for all so that society can focus its attention on the possibilities for human medicine that SCNT-therapeutic cloning-represents.

In the absence of guiding federal legislation banning reproductive cloning, and 
thereby separating it from the discussions about SCNT and its therapeutic possibilities, it seems time to reconsider what the U.S. Food and Drug Administration (FDA) has said and done about reproductive cloning. If FDA's authority and actions over reproductive cloning are firmly established and unassailable, then one can say with some certainty that the matter has been finally put to rest. We can then focus our attention on regulation of SCNT without being encumbered by the ethical baggage of reproductive cloning.

Many assume that FDA's regulatory jurisdiction over human reproductive cloning is unassailable, and that the agency has clear authority to initiate enforcement proceedings against would-be cloners and shut them down. Recall the case of Clonaid, the so-called human cloning company, that made the outrageous and later discredited claim in Florida in December 2002 that it had cloned the first child, "Baby Eve." In fact, in 2001, the FDA sent inspectors to Nitro, West Virginia, to see firsthand Clonaid's cloning laboratory; they found nothing to suggest that it had the actual capacity to clone [103], but what if today a rogue laboratory in a jurisdiction that had not banned human reproductive cloning announced that it was attempting to clone an embryo with the intent of producing a cloned human child? How would the FDA react and on what legal authority? What if the firm announced that it had in fact cloned a human child? What if this had been true? Would the FDA send a U.S. Marshal to seize the child under the agency's seizure authority? ${ }^{2}$ What would it do with the child then? Perhaps FDA would criminally prosecute the individual per-

\footnotetext{
${ }^{1}$ See Chung-Ying Wu, "A Hypothetical Case: United States v. Clonaid," p. 6 (March 2003), in Electronic Book of Harvard Law Student Papers on Food and Drug Law, available at http://dash .harvard.edu/handle/1/8963881 The claim was challenged in court by one of the authors of this article (B.S.). See Bernard Siegel,"Reflections on the Cloning Case," Cloning and Stem Cells, 9(1):40-47 (2007), available at http://bernardsiegel.com/Reflections-on-CloningCase.pdf

221 U.S.C. §334(a).
}

petrators who were responsible for cloning Baby Eve and put them in jail. ${ }^{3}$ Or maybe the agency would seek an injunction to forestall the cloning of additional babies in the future. ${ }^{4}$ Would the court in any such enforcement proceeding conclude that FDA has the underlying authority to regulate human cloning?

As a consequence, the time may be ripe for the FDA to review the agency's organic statutes, perhaps through notice and comment rulemaking under the Federal Administrative Procedure Act, ${ }^{5}$ and to clarify the basis for its regulation of human reproductive cloning. If FDA concludes that there are gaps in its authority, then it may be wise for the agency to seek greater clarity on the matter from Congress. ${ }^{6}$ This may help preserve the promise of SCNT in therapeutic cloning, while at the same time insuring that the technology is not misused for reproductive cloning.

In his thoughtful 2002 law review article [2], former FDA chief counsel and University of Virginia professor of law Richard A. Merrill traces what, in his view, may best be characterized as FDA's somewhat meager claim, substantively and procedurally, to the authority over regulating human cloning (see also [3]). On the other hand, Louis M. Guenin, lawyer and lecturer on ethics and science in the Department of Microbiology and Immunology at Harvard Medical School, in an equally thoughtful article [4] makes a strong case that the FDA has the substantive authority to regulate human reproductive cloning and that its authority was announced in a procedurally appropriate way. Guenin's analysis is grounded in detailed scientific analysis that he measures against what he argues are relevant statutory and regulatory provisions. On careful review, however, we

\footnotetext{
${ }^{3} 21$ U.S.C. $\$ 333$.

${ }^{4} 21$ U.S.C. $\$ 332$.

55 U.S.C. $\$ 553$.

${ }^{6}$ Should a court conclude that the FDA lacks jurisdiction over reproductive human cloning, it seems likely that Congress would immediately step in to ban the practice.
}

question the adequacy of the "process" FDA followed when announcing its authority in the area. The agency's failure to subject its analysis of authority to any public scrutiny and comment is the most compelling procedural defect in its claim of authority. The underlying concerns about openness and transparency-due process - that are expressed in the Administrative Procedure Act have simply not been met. Courts have repeatedly instructed agencies that regulated parties are not required to engage in inference and guesswork to determine an agency's regulatory authority over a given topic ${ }^{7}$ just the opposite. It is the agency's responsibility to tell the public why it believes that it has the authority to do what it has done.

Consider how the FDA went about announcing its claim of authority over reproductive cloning. It was not made through notice-and-comment rulemaking; nor was it even the product of an official FDA "guidance" of any sort. ${ }^{8}$ Instead, as Professor Merrill recounts, the FDA's assertion of its authority in the area came in the form of an answer to a question asked of the then-acting FDA commissioner in the course of a radio interview. This was followed a few days later by a unilateral declaration of authority, without explanation, that appeared in a letter from the FDA's deputy commissioner for external affairs to Senator Edward Kennedy. On October 26, 1998, the FDA's associate commissioner for medical affairs sent a letter to the Nation's institutional review boards concluding-again without analysisthat the FDA has jurisdiction, at least over clinical trials that are intended to study reproductive human cloning, under its authority over Investigational

\footnotetext{
${ }^{7}$ See, for example, the State of New York v. Interstate Commerce Commission, 342 U.S. 911 (1951) (Black, J., dissenting from disposition of case without oral argument). “Unless we make the requirements for administrative action strict and demanding...the strength of modern government, can become a monster which rules with no practical limits on its discretion. Absolute discretion, like corruption, marks the beginning of the end of liberty." 821 CFR $\$ 10.115$
} 
New Drug applications (INDs). Again, in congressional testimony in 2001, the then-director of the FDA's Center for Biologics Evaluation and Research likewise reiterated the FDA's position on the matter.

For the most part, that's it (see also [104]). The simple fact is that procedural niceties intended to insure public participation and deliberate agency consideration of all views in a matter of this magnitude were not only largely missing; they were entirely absent. So too was any detailed analysis of the substantive basis for the FDA's position. It is true of course that the FDA said it had jurisdiction according to its IND authority over clinical trials involving reproductive human cloning, but there was no real analysis in the FDA's informal pronouncements of its authority that would confirm the agency's interpretation. Moreover, and while the FDA claimed that it could regulate clinical trials in this area, it did not explain why and how it had any underlying product jurisdiction over this technology. In our view, it is hard to credit seriously a claim of authority over the testing of an FDA-regulated article without knowing why and how the agency has jurisdiction over the final "product" - in this case, a cloned human being - of such testing. While both Merrill and Guenin each posit alternate bases for FDA's jurisdiction over human reproductive cloning-for example, regulating it under the agency's authority over gene therapy-these legal theories have not been advanced by the FDA in any principled way.

It is certainly not enough to argue that a court in an enforcement action against a would-be cloner will necessarily defer to the FDA's own claim to jurisdiction over human reproductive cloning. Thus, the argument runs, there is no need for further amplification of the agency's position through an administrative proceeding with a greater degree of formality than the conclusory ipse dixit announcements the FDA made on the subject more than 10 years ago. No doubt, proponents of this deference argument would point to the U.S. Supreme Court's recent decision in City of Arlington v. Federal Communi- cations Commission. ${ }^{9}$ There, the question was whether the Federal Communications Commission's determination of its own authority to adopt specific interpretations of ambiguous statutory provisions was entitled to judicial deference under the socalled Chevron doctrine. ${ }^{10}$ This doctrine holds that where there is ambiguity, courts will defer to an administrative agency's own reasonable interpretation of its own organic statutes. At least according to the majority opinion in City of Arlington, courts must apply Chevron and defer to an agency's determination of the scope of its own jurisdiction, even "where concerns about the agency's self-aggrandizement are at their apogee: in cases where an agency's expansive construction of the extent of its own power would have wrought a fundamental change in the regulatory scheme." 11 Indeed, in reaching this conclusion, Justice Scalia relies on an earlier case in which the Court evaluated an assertion of jurisdiction over of a particular product by FDA itself by applying the Chevron framework. $^{12}$

This reflexive application of the Chevron doctrine presupposes that an agency's determination of its own jurisdiction was reached in a proceeding that had the requisite degree of formality to justify that kind of deference, but the Supreme Court itself has held that judicial deference under Chevron is not necessarily to be accorded to any and all agency musings that touch on a matter within its domain. ${ }^{13}$ On the contrary, as explained in City of Arlington, "for Chevron deference to apply, the agency must have received congressional authority to determine the particular matter at issue in the particular manner adopted." 14 It seems apparent that, even if Congress had delegated authority to FDA to determine whether human reproductive cloning is subject to the agency's jurisdic-

9 _U.S._, 2013 WL 2149789 (May 20, 2013).

${ }^{10}$ Chevron U.S.A. Inc. v. Natural Resources Defense Counsel, Inc., 467 U.S. 837 (1984).

${ }^{11} / d$. at ${ }^{*} 9$.

${ }^{12} / d$.

${ }^{13}$ See, for example, United States v. Mead Corp., 533 U.S. 218 (2001).

${ }^{14} 2013$ WL 2149789 at *10 (second emphasis added).

\section{The Path to the FDA's Regulation of Human Reproductive Cloning \\ - Undertake a deliberate process to authoritatively establish its jurisdiction over reproductive cloning \\ - Solicit and consider input from all stakeholders to explore the boundaries of therapeutic cloning and the beneficial use of SCNT \\ - Delineate the legal and regulatory distinctions between therapeutic and reproductive cloning \\ - Provide a proceeding for possible legislative consideration}

tion, it did not intend for that authority to be exercised via radio interview or any other way, such as informal letters to the industry, ${ }^{15}$ that FDA used to announce its position on the matter. Thus, according to this analysis, the FDA's claim of deference to its own determination of authority in this area may well be rejected by a court. This would leave the question of the FDA's authority over reproductive cloning to a court to determine in an enforcement action against a would-be cloner (or for perhaps the court to remand the matter to the FDA for commencement of a more formal procedure to reach a definitive conclusion on the matter). This hardly seems the right way to run a regulatory railroad.

The point we make is simple and straightforward. The FDA should undertake a deliberate process to authoritatively establish its jurisdiction over human reproductive cloning. This would directly address the problem of the would-be human cloner in a binding way. At the same time, such a principled proceeding would give the agency an opportunity, with input from all stakeholders, to explore the boundaries of therapeutic cloning and the beneficial use of SCNT as well as the legal

\footnotetext{
${ }^{15}$ In Mead, the court declined to accord Chevron deference to a tariff classification determination expressed in a letter from the U.S. Customs Service.
} 
and regulatory distinctions between the therapeutic and reproductive cloning. In this way, the FDA would provide a solid foundation for disaggregating the two and thereby remove the apparent rate limiting factor of reproductive cloning in assessing the value of therapeutic cloning. Should Congress elect to step in and revisit the matter again, an FDA proceeding would provide a useful foundation for legislative consideration - or reconsideration. In theory anyway, this should foster the lifesaving potential of therapeutic cloning. In our view, the time is ripe for the FDA to undertake such an initiative.

\section{Author disclosure statement}

No competing financial interests exist.

\section{REFERENCES}

\section{Primary Literature}

1. Tachibana M et al. (2013). Human embryonic stem cells derived by somatic cell nuclear transfer. Cell 153:12281238 .

2. Merrill RA. (2002). Human tissues and reproductive cloning: new technologies challenge FDA. Houst J Health Law Policy 3:1-82.

3. Merrill RA and BJ Rose. (2001). FDA regulation of human cloning: usurpation or statesmanship? Harv J Law Technol 15:85-148.

4. Guenin LM. (2005). Stem cells, cloning, and regulation. Mayo Clin Proc 80:241-250.

\section{Websites}

101. California Institute for Regenerative Medicine. Oregon research team derives embryonic stem cells via nuclear transfer. June 2013 Newsletter. www.cirm. ca.gov/about-cirm/newsletter/june-2013newsletter\#scnt

102. California Institute for Regenerative Medicine Blog Post. Caffeine held the key to creating embryonic stem cells from cloned embryos. May 15, 2013. http:/cirmresearch.blogspot.com/2013/ 05/caffeine-held-key-to-creating-embry onic.html

103. For Clonaid, a trail of unproven claims. N.Y. Times, January 1, 2003. www.nytimes.com/2003/01/01/us/forclonaid-a-trail-of-unproven-claims .html

104. U.S. Food and Drug Administration. Cloning. Vaccines, Blood \& Biologics. www.fda.gov/BiologicsBloodVaccines/ CellularGeneTherapyProducts/Cloning/ default.htm 